\title{
OBSERVATIONS ON THE SURVIVAL OF WASHED BOAR SPERMATOZOA IN DIFFERENT MEDIA
}

\author{
I. G. WHITE* AND R. A. P. HARRISON \\ ARC Unit of Reproductive Physiology and Biochemistry, Cambridge $\dagger$
}

(Received 13th Fanuary 1971)

Semen, collected from boars of proven fertility, was concentrated by centrifuging the strained ejaculate at $400 \mathrm{~g}$ for $15 \mathrm{~min}$ at $20^{\circ} \mathrm{C}$ and gently resuspending the sperm pellet in one-fifth the original volume of seminal plasma. The concentrated semen was then diluted $1: 6$ either in a chosen wash medium (see Table 1 for composition of media) and used immediately, or in a milk diluent (MFP), cooled slowly to $5^{\circ} \mathrm{C}$ over a period of $5 \mathrm{hr}$, and stored overnight at $5^{\circ} \mathrm{C}$.

The spermatozoa were washed by centrifugation at $400 \mathrm{~g}$ for $12 \mathrm{~min}$ followed by gentle resuspension in a fresh aliquot of the chosen wash medium. Three centrifugations were carried out and samples of the final pellet were resuspended in chosen media. All manipulations of fresh semen were carried out at $20^{\circ} \mathrm{C}$, whereas all manipulations of stored semen were carried out at $5^{\circ} \mathrm{C}$, and various combinations of wash medium and resuspension medium were tested.

Spermatozoa in the final resuspension media were incubated at $37^{\circ} \mathrm{C}$ with frequent aeration with a Pasteur pipette, and scored for motility (Emmens, 1947) after 0, 1, 2 and $3 \mathrm{hr}$ by examining a drop of the sperm suspension on a warmed microscope slide under low power magnification in a hot box maintained at $37^{\circ} \mathrm{C}$. The identity of each preparation was known to the observer.

Cooling boar semen to $5^{\circ} \mathrm{C}$ at $0.5^{\circ} \mathrm{C} /$ min caused an irreversible depression of motility. In semen cooled slowly after dilution in MFP, motility was restored on warming. Washing the stored spermatozoa reduced their motility when they were finally resuspended in RFP (Table 1). While the use of the sperm-rich fraction (Polge, 1956), or the addition of $2.5 \mathrm{mg}$ bovine serum albumin $/ \mathrm{ml}$ (Choong \& Wales, 1962) or $0.75 \mathrm{mg}$ vitamin E/ml to the SP wash medium did not improve maintenance of motility after washing, final resuspension of the washed spermatozoa in MFP did restore their motility.

A further experiment was carried out using, as wash medium, MFP, SE or RFP and, as resuspension medium, MFP, MSP, MRFP, SP RFP or SE (Table 1). Samples of stored spermatozoa were also centrifuged three times and resuspended in their own supernatant as a control.

The results (Table 2) indicated that the composition of the final resuspension medium was much more important than that of the wash medium, highly

\footnotetext{
* Present address: Department of Veterinary Physiology, University of Sydney, Sydney 2006, Australia.

$\dagger$ Postal address: Animal Research Station, 307 Huntingdon Road, Cambridge CB3 OJQ,England.
} 
TABLE 1

COMPOSITION OF MEDIA

MFP: $2 \% \mathrm{w} / \mathrm{v}$ dialysed heat-treated skim-milk solids, $200 \mathrm{~mm}$-fructose, $19 \mathrm{~mm}-\mathrm{NaH}_{2} \mathrm{PO}_{4}, 31 \mathrm{~mm}-$ NaCl, 5 mM-KOH, adjusted to $\mathrm{pH} 7 \cdot 0$ with $\mathrm{NaOH}$ (Harrison \& White, unpublished data). FP: As MFP, but omitting the milk solids.

MSP: As MFP, but substituting sucrose for fructose.

SP: $\quad$ As MSP, but omitting the milk solids.

MRFP: $2 \% \mathrm{w} / \mathrm{v}$ dialysed heat-treated skim-milk solids, dissolved in Ringer-fructose-phosphate (Mann, 1964).

RFP: Ringer-fructose-phosphate (Mann, 1964).

SE: $\quad 300$ mM-sucrose, 4 mM-Na $\mathrm{NaDT}_{2}$, adjusted to $\mathrm{pH} 7 \cdot 0$ with $\mathrm{KOH}$.

\section{TABLE 2}

THE MOTILITY OF BOAR SPERMATOZOA PREVIOUSLY GOOLED OVERNIGHT IN A MILK DILUENT AFTER WASHING AND RESUSPENDING IN VARIOUS MEDIA AT $5^{\circ} \mathrm{C}$

\begin{tabular}{l|cccccc|c}
\hline \multirow{2}{*}{$\begin{array}{l}\text { Wash } \\
\text { medium }\end{array}$} & \multicolumn{6}{|c|}{ Final resuspension medium } & \multirow{2}{*}{ Mean } \\
\cline { 2 - 8 } & $M F P$ & $M S P$ & $S P$ & $M R F P$ & $R F P$ & $S E$ & \\
\hline Nil* & 22 & 21 & 19 & 18 & 16 & 15 & 19 \\
MFP & 21 & 18 & 18 & 17 & 15 & 11 & 17 \\
SE & 23 & 17 & 18 & 16 & 17 & 12 & 17 \\
RFP & 25 & 19 & 18 & 16 & 16 & 14 & 18 \\
\hline Mean & $23 \dagger$ & 19 & 19 & 17 & 16 & $13 \ddagger$ & \\
\hline
\end{tabular}

The results represent the mean Motility Index for three ejaculates (Motility Index $=\left(\right.$ sum of motility scores after 1,2 and $3 \mathrm{hr}$ at $37^{\circ} \mathrm{C}$ ) $\times 4$ ).

* Spermatozoa centrifuged and resuspended without washing.

$\dagger$ Different from all others $(P<0.01)$.

$\$$ Different from all others except RFP $(P<0.01)$.

significant differences being detected amongst the former. Motility indices were highest when spermatozoa were resuspended in MFP and lowest when they were resuspended in SE. With or without milk solids, RFP was not a good resuspension medium.

The effect of RFP was tested on spermatozoa washed at $20^{\circ} \mathrm{C}$ immediately after concentration. The results (Table 3 ) indicated that RFP at $20^{\circ} \mathrm{C}$ was as satisfactory as any of the other media for washing or resuspending boar spermatozoa. However, the FP medium was unsatisfactory both for washing and for resuspension.

When spermatozoa that had been washed at $5^{\circ} \mathrm{C}$ were resuspended and incubated at $37^{\circ} \mathrm{C}$, prolonged incubation was often necessary to obtain maximum motility (Text-fig. 1), though this was a variable phenomenon. However, when the motility of a cooled sample showed an increase after $1 \mathrm{hr}$ at $37^{\circ} \mathrm{C}$, this increase was evident in all subsamples, irrespective of the washing or resuspension media.

While these results underline the sensitivity of boar semen to low temperatures (Lasley \& Bogart, 1944), it is possible to obtain preparations of motile washed boar spermatozoa essentially free both of seminal plasma and of cytoplasmic droplets (Harrison \& White, in preparation) by first diluting in a milk 
TABLE 3

THE MOTILITY OF FRESHLY GOLLECTED BOAR SPERMATOZOA AFTER WASHING AND RESUSPENDING IN VARIOUS MEDIA AT ROOM TEMPERATURE

\begin{tabular}{l|ccccc|c}
\hline \multirow{4}{*}{$\begin{array}{c}\text { Wash } \\
\text { medium }\end{array}$} & \multicolumn{5}{|c|}{ Final resuspension medium } & \multirow{2}{*}{ Mean } \\
\cline { 2 - 6 } & MFP & FP & MRFP & RFP & $S P$ & \\
\hline MFP & 31 & 16 & 35 & 31 & 41 & 31 \\
FP & 26 & 12 & 29 & 25 & 29 & $24 \dagger$ \\
MRFP & 28 & 21 & 30 & 28 & 29 & 27 \\
RFP & 37 & 21 & 33 & 32 & 33 & 31 \\
\hline Mean & 31 & $18^{*}$ & 32 & 29 & 33 & \\
\hline
\end{tabular}

The results represent the mean Motility Index for three ejaculates (Motility Index $=$ (sum of motility scores after 1, 2 and $3 \mathrm{hr}$ at $\left.37^{\circ} \mathrm{C}\right) \times 4$ ).

* Different from all others $(P<0.01)$.

$\dagger$ Different from MF and $R(P<0.01)$.

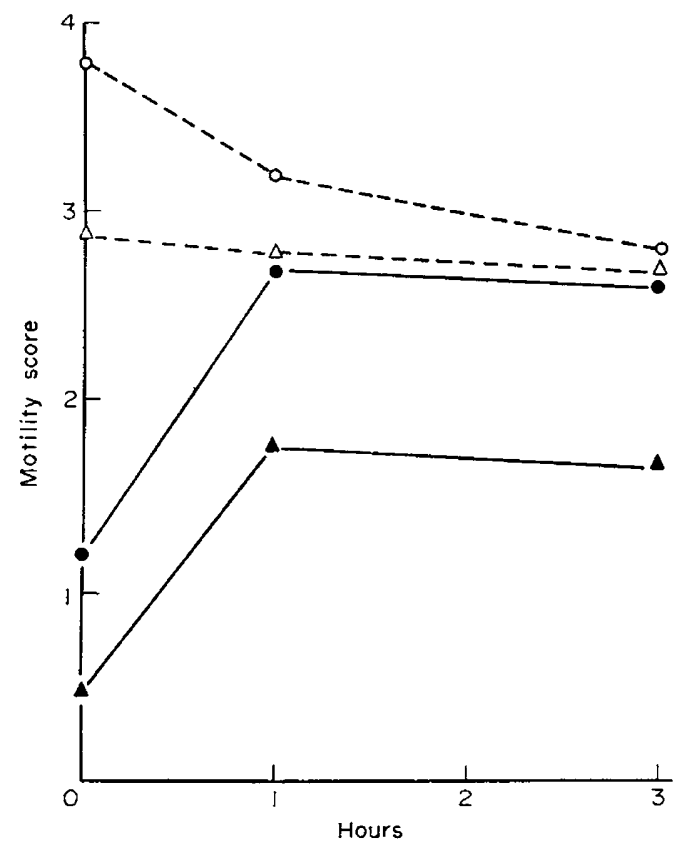

TeXT-FIG. 1. The motility of washed boar spermatozoa after resuspension in different media. Each point represents the mean for three ejaculates. Symbols used: $O$, resuspension in MFP after washing in RFP at $20^{\circ} \mathrm{C} ; \Delta$, resuspension in RFP after washing in RFP at $20^{\circ} \mathrm{C}$; 0 , resuspension in MFP after washing in RFP at $5^{\circ} \mathrm{C}$ following storage overnight at $5^{\circ} \mathrm{C} ; A$, resuspension in RFP after washing in RFP at $5^{\circ} \mathrm{C}$ following storage overnight at $5^{\circ} \mathrm{C}$.

diluent, and cooling very slowly to $5^{\circ} \mathrm{C}$. RFP must be avoided as a resuspension medium after washing cooled boar spermatozoa at $5^{\circ} \mathrm{C}$ if good motility on rewarming is desired, even though RFP appears satisfactory as a resuspension medium for spermatozoa washed at $20^{\circ} \mathrm{C}$ (cf. Aalbers, Mann \& Polge, 1961). 
It is not possible from these experiments to explain the adverse effects of RFP at low temperatures. The absence of milk solids is not a factor since motility in MRFP was little better than in RFP, also the presence of bicarbonate and magnesium (as in RFP) might be expected to enhance motility. One feature of the Ringer diluent, however, is the high electrolyte to non-electrolyte ratio due to the high $\mathrm{NaCl}$ content. Many years ago, Milovanov (1934) advanced the theory that electrolytes were harmful to boar spermatozoa and destroyed the 'lipid capsule' surrounding the head; such an effect might be aggravated by cold shock to which boar spermatozoa are particularly susceptible. The most promising diluent used in A.I. practice for diluting boar semen, the modified Illinois Variable Temperature diluent, contains relatively little electrolyte (Bennett \& O'Hagan, 1964).

The unsatisfactory nature of FP (Table 3 ) is surprising since the replacement of fructose by sucrose (SP) or the inclusion of milk solids (MFP) gave good results. High levels of fructose may be detrimental to the metabolism of boar spermatozoa in the absence of the high molecular weight material in milk, for Foley, Marsh, Heidenreich, Garwood \& Erb (1967), studying washed boar sperm suspensions, found lower motility and metabolism associated with a diluent containing $72 \mathrm{~mm}$-fructose.

The lag in the reactivation of boar spermatozoa after cooling to $15^{\circ} \mathrm{C}$ has been noticed by other workers (see Polge, 1956), and seems to be even more marked when the semen is cooled to $5^{\circ} \mathrm{C}$. The present experiments underline the necessity to leave stored spermatozoa for some time at $37^{\circ} \mathrm{C}$ before rejecting such samples as dead. Anaerobically, boar spermatozoa convert fructose to lactate at a much lower rate than ram or bull spermatozoa and motility is also depressed (Aalbers et al., 1961; Foley, Heidenreich, Harrington, Jones \& Erb, 1964); however, in limited experiments, we did not detect any difference in the subsequent motility and revival of boar spermatozoa when suspensions in the milk diluent were aerated with $\mathrm{O}_{2}$ or $\mathrm{N}_{2}$ during storage at $5^{\circ} \mathrm{C}$.

\section{REFERENCES}

Aalbers, J. G., Mann, T. \& Polge, G. (1961) Metabolism of boar semen in relation to sperm motility and survival. 7. Reprod. Fert. 2, 42.

BennetT, G. H. \& O'HAGAN, C. (1964) Factors influencing the semen of artificial insemination of pigs. Proc. V Int. Congr. Reprod. Artif. Insem. 4, 481.

Ghoong, G. H. \& Wales, R. G. (1962) The effect of cold shock on spermatozoa. Aust. F. biol. Sci. 15, 543.

Emmens, C. W. (1947) The motility and viability of rabbit spermatozoa at different hydrogen-ion concentrations. F. Physiol., Lond. 106, 471.

Foley, C. W., Heidenreich, C. J., Harrington, R. B., Jones, H. W. \& ERB, R. E. (1964) Changes in fructose, lactic acid, $\mathrm{pH}$ and motility of boar semen during incubation at $37^{\circ}$ C. F. Anim. Sci. 23, 558.

Foley, G. W., Marsh, H. M., Heidenreich, C. J., Garwood, V. A. \& ERB, R. E. (1967) Effects of zero and three-day storage of washed boar spermatozoa on subsequent incubation characteristics. 7. Anim. Sci. 26, 1072.

LASLEY, J. F. \& BOGART, R. (1944) Some factors affecting the resistance of ejaculated and epididymal spermatozoa of the boar to different environmental conditions. Am. F. Physiol. 141, 619 .

MANN, T. (1964) The biochemistry of semen and of the male reproductive tract, 2nd edn. Methuen, London. Mrlovanov, V. K. (1934) Principles of artificial insemination. State Publishing House, Moscow-Leningrad. Polge, C. (1956) Artificial insemination in pigs. Vet. Rec. 68, 62. 